\title{
A case of anti-GBM glomerulonephritis superimposed on HBV-associated membranous nephropathy
}

\author{
Takeshi Yamamoto $\cdot$ Susumu Oseto • \\ Natsuko Imakita $\cdot$ Masami Inada $\cdot$ Megumu Fukunaga
}

Received: 23 March 2012/ Accepted: 25 February 2013/Published online: 13 April 2013

(C) Japanese Society of Nephrology 2013

\begin{abstract}
In September 2010, a 75-year-old hepatitis B virus (HBV)-positive man was admitted to our hospital because of fever, persistent cough, general fatigue, and leg edema. The patient was a hepatitis B surface antigen carrier with detectable HBV DNA level. On admission, laboratory examination revealed severe inflammatory signs, decreased serum albumin, and renal insufficiency with proteinuria. The patient had rapidly progressive renal insufficiency without pulmonary involvement over the few days after admission. Renal biopsy showed membranous nephropathy (MN) with crescent formation. Further serological study revealed a high titer of anti-glomerular basement membrane (GBM) antibody, suggestive of anti-GBM glomerulonephritis superimposed on HBV-associated MN. For both preventing $\mathrm{HBV}$ reactivation during immunosuppressive therapy and treating $\mathrm{HBV}$-associated $\mathrm{MN}$, the administration of entecavir was immediately initiated, and then treatment with plasma exchange (PE) and intravenous methylprednisolone administration was performed. Both
\end{abstract}

T. Yamamoto

Department of Nephrology, Osaka University Graduate School

of Medicine, Suita, Osaka, Japan

S. Oseto $\cdot$ M. Fukunaga ( $\square)$

Division of Nephrology, Department of Medicine,

Toyonaka Municipal Hospital, 4-14-1 Shibahara-cho,

Toyonaka, Osaka 560-8565, Japan

e-mail: mfukuna@ba2.so-net.ne.jp

N. Imakita

Division of Nephrology, Osaka Rosai Hospital, Sakai,

Osaka, Japan

M. Inada

Division of Gastroenterology/Hepatology, Toyonaka Municipal

Hospital, Toyonaka, Osaka, Japan
HBV DNA level and an anti-GBM titer became undetectable, and clinical remission of $\mathrm{MN}$ was subsequently achieved. This was a rare case of an elderly patient with anti-GBM glomerulonephritis superimposed on HBVassociated MN, who was successfully treated with PE, corticosteroid, and entecavir combination therapy.

Keywords Hepatitis B virus - Membranous nephropathy · Entecavir · Immunosuppressive therapy

\section{Introduction}

Membranous nephropathy (MN) is a well-recognized extrahepatic manifestation of chronic infection with hepatitis B virus (HBV). Although the pathogenesis of this association is unclear, immune complex deposition has been implicated [1]. Antiviral treatment with interferonalpha (IFN- $\alpha$ ) and lamivudine has been reported to be beneficial $[2,3]$. In recent years, entecavir has been used as an antiviral treatment for chronic hepatitis B patients. Since resistance to entecavir is rare, entecavir can be used for a long period and will benefit patients with $\mathrm{HBV}$-associated $\mathrm{MN}$ as well.

On the other hand, anti-glomerular basement membrane (GBM) disease (also known as Goodpasture's syndrome when associated with pulmonary hemorrhage) is a relatively rare entity characterized by antibodies to type IV collagen of glomerular and alveolar basement membranes. When only the kidney is involved, the disease is commonly known as anti-GBM glomerulonephritis. The simultaneous occurrence of both anti-GBM disease and $\mathrm{MN}$ has been infrequently described [4-30]. However, anti-GBM glomerulonephritis superimposed on secondary $\mathrm{MN}$ such as $\mathrm{HBV}$-associated $\mathrm{MN}$ is exceptionally rare and there has 
been only one case reported in the literature [28]. The case reported here is a rare occurrence of an elderly patient with anti-GBM glomerulonephritis superimposed on HBVassociated MN successfully treated with plasma exchange (PE), corticosteroid, and entecavir combination therapy. We describe the clinical and histological features of the patient, review previously reported cases, and discuss the treatment for this complicated entity, as well as possible implications for the pathogenesis of the co-existence of these lesions.

\section{Case report}

In September 2010, a 75-year-old HBV-positive man experienced flu-like symptoms persisting for more than a week and presented to the emergency department of our hospital because of fever, persistent cough, general fatigue, and leg edema. He was a lifelong nonsmoker. Regarding the patient's medical history, HBV infection was diagnosed 20 years ago. He had been under outpatient care at our hospital and taking ursodeoxycholic acid, and his laboratory data at the last follow-up of 3 months before admission showed normal serum transaminases, normal serum creatinine $(0.81 \mathrm{mg} / \mathrm{dl})$, low serum albumin $(3.1 \mathrm{~g} / \mathrm{dl})$, and urinalysis with $2+$ proteinuria and $1+$ hematuria. Regarding the family history, his mother died of hepatic carcinoma. On admission, laboratory examination revealed severe inflammatory signs, proteinuria, hematuria, decreased serum albumin, and renal insufficiency. His blood pressure was $156 / 79 \mathrm{mmHg}$ and temperature was $37.1^{\circ} \mathrm{C}$. Heart sounds were clear with a regular sinus rhythm and pulse rate was 76 beats/min. Respiratory sound was normal and respiration rate was $18 / \mathrm{min}$. No symptoms suggestive of urinary or abdominal infection were apparent. Physical examination showed weight loss from 44 to $40 \mathrm{~kg}$, anemic conjunctiva, and mild edema in both feet. The abdomen was soft and flat, with neither hepatosplenomegaly nor palpable masses. No hemoptysis, skin rash, livedo reticularis, muscle tenderness, or arthralgia was observed. Chest radiography revealed mild cardiac enlargement and bilateral pleural effusions. A computed tomography (CT) scan of his chest revealed no granuloma formation, pulmonary hemorrhage, or interstitial pneumonia. Renal ultrasonography showed normal kidney appearance. Renal vein thrombosis was ruled out with Doppler ultrasonography of the renal vessels.

Laboratory findings were as follows: white blood cell (WBC) count, 10900/ $\mu$ l (neutrophils, $80.3 \%$; eosinophils, $1.0 \%$; lymphocytes, $10.8 \%$ ); red blood cell (RBC) count, $395 \times 10^{4} / \mu \mathrm{l}$; hemoglobin, $10.4 \mathrm{~g} / \mathrm{dl}$; hematocrit, $32.3 \%$; platelet count, $26.3 \times 10^{4} / \mu \mathrm{l}$; reticulocytes, $0.5 \%$; erythrocyte sedimentation rate (ESR), $110 \mathrm{~mm} / \mathrm{h}$; total protein,
$5.2 \mathrm{~g} / \mathrm{dl}$; albumin, $1.7 \mathrm{~g} / \mathrm{dl}$; aspartate aminotransferase (AST), $23 \mathrm{IU} / 1$; alanine aminotransferase (ALT), $14 \mathrm{IU} / \mathrm{l}$; lactic dehydrogenase (LDH), $200 \mathrm{IU} / 1$; blood urea nitrogen (BUN), $17 \mathrm{mg} / \mathrm{dl}$; creatinine $(\mathrm{Cr}), 1.93 \mathrm{mg} / \mathrm{dl}$; C-reactive protein (CRP), $14.0 \mathrm{mg} / \mathrm{dl}$; and $\mathrm{HbAlc}, 5.4 \%$. As pulmonary hemorrhage, gastrointestinal bleeding, or malignancy were detected by routine examinations, chronic inflammatory status, renal anemia, and malnutrition were considered as the cause of his normochromic normocytic anemia. Anti-hepatitis $\mathrm{C}$ virus (HCV) and anti-human immunodeficiency virus (HIV) antibody tests were negative, but hepatitis B surface antigen ( $\mathrm{HBsAg}$ ) and hepatitis $\mathrm{B}$ e-antibody ( $\mathrm{HBeAb}$ ) were positive (often called 'inactive carrier phase') and HBV DNA [by real-time polymerase chain reaction (PCR)] was detectable (2.7 log copies/ml). Urinalysis revealed urinary protein excretion of about $1.8 \mathrm{~g} / 24 \mathrm{~h}$ (a spot protein-to-creatinine ratio of $2.9 \mathrm{~g} / \mathrm{g}$ creatinine), $3+$ hematuria, sediment containing $>100$ RBCs and 1-4 WBCs per high-power field (HPF), and various types of cast [10-19 granular casts, 30-49 hyaline casts, 20-29 epithelial casts per whole field (WF)]. Urinalysis suggested active glomerulonephritis. Serum and urine protein electrophoresis did not reveal anomalous immunoglobulins. Further serological study showed that anti-nuclear antibody (ANA) (nuclear membrane-staining pattern) was 40-fold positive. Anti-GBM antibody (the corresponding antigen to which this anti-GBM antibody reacts is the noncollagenous $\mathrm{NC} 1$ domain of the $\alpha 3$ chain of type IV collagen) exceeded $300 \mathrm{EU}$ (normal range $<10 \mathrm{EU}$ ), while myeloperoxidase-antineutrophil cytoplasmic antibody (MPO-ANCA), proteinase-3 (PR3)-ANCA, anti-DNA antibody, and cryoglobulin were not present. Serum immunoglobulins were as follows: $\mathrm{IgG}$ was normal $(1,024 \mathrm{mg} / \mathrm{dl}), \operatorname{IgM}$ was normal $(64 \mathrm{mg} / \mathrm{dl})$, and $\operatorname{IgA}$ was high $(574 \mathrm{mg} / \mathrm{dl})$. Serum complement levels were all normal: C3 was $88 \mathrm{mg} / \mathrm{dl}, \mathrm{C} 4$ was $35 \mathrm{mg} / \mathrm{dl}$, and CH50 was $32.5 \mathrm{U} / \mathrm{ml}$.

Initially, the patient's renal insufficiency was thought to be due to decreased renal perfusion in the setting of fever, decreased oral intake, and hypoalbuminemia. However, over the first few days after admission, his renal function rapidly deteriorated; on the 8th and 15th days of admission, his $\mathrm{Cr}$ level increased to 2.71 and $3.58 \mathrm{mg} / \mathrm{dl}$, respectively. Because of the systemic signs and symptoms, lack of response to fluids and antibiotics, rapidly progressive renal insufficiency with active nephritic urinary sediments, and negative findings for systemic infection or malignancy, percutaneous renal biopsy was done on the 10th day of admission. Renal biopsy specimen for light microscopy containing 25 glomeruli revealed MN with mild diffuse mesangial proliferation, diffuse thickening of GBMs, occasional capillary wall subepithelial spikes, and frequent internal vacuolization on periodic acid-silver methenamine 
(PAM) staining (Fig. 1a). Five of 25 glomeruli were globally sclerotic, and 9 of 25 glomeruli showed cellular crescents and segmental necrosis, with compression or destruction of capillary loops and Bowman's capsule (Fig. 1b). Around glomeruli with crescent formation, severe tubulointerstitial damage was seen and was accompanied by the infiltration of lymphocytes, plasma cells, neutrophils, and eosinophils, but not by vasculitis (Fig. 1c). Chronic changes such as tubular atrophy, interstitial fibrosis, and chronic hypertensive vascular disease were also observed. Immunofluorescence staining revealed diffuse granular staining of $\operatorname{IgG}(2+), \mathrm{C} 3(1+), \operatorname{IgA}(1+)$, and $\operatorname{IgM}( \pm)$ on capillary loops. In addition, an underlying linear staining of the GBMs could be discerned for IgG and C3 (Fig. 1d). Staining for C4, C1q, and fibrinogen was essentially negative. Electron microscopy showed numerous scattered subepithelial and intramembranous deposits, and complete overlying foot process effacement (Fig. 1e). Some of these subepithelial deposits appeared electronlucent. Moreover, occasional mesangial deposits and mesangial proliferation were present, in a distribution characteristic of secondary MN. There was no evidence of an organized substructure within deposits, and overt subendothelial deposits, reticular aggregates, or virus-like spherical microparticles were present. We further performed $\mathrm{HBsAg}$ immunohistochemistry using paraffinembedded section, but the glomerular deposition of HBsAg was not demonstrated in our immunohistochemical specimen. As we could not find positive staining for HBsAg and this patient did not have $\mathrm{HBeAg}$, though most patients with $\mathrm{HBV}$-associated $\mathrm{MN}$ have $\mathrm{HBeAg}$, it was quite difficult to accurately diagnose whether his $\mathrm{MN}$ was primary or secondary to HBV. We consulted with an expert pathologist of renal pathology. On the basis of positive laboratory data such as HBsAg and HBV DNA and pathological findings such as mesangial deposits, mesangial proliferation, and transitional features between $\mathrm{MN}$ and membranoproliferative glomerulonephritis (MPGN), the patient was finally diagnosed as having anti-GBM glomerulonephritis superimposed on HBV-associated MN (stage III-IV).

For both preventing $\mathrm{HBV}$ reactivation in immunosuppressive therapy and treating $\mathrm{HBV}$-associated $\mathrm{MN}$, the administration of entecavir (Baraclude ${ }^{\circledR}$, Bristol-Myers Squibb Company, New York, USA) at a dose of $0.5 \mathrm{mg} /$ day was immediately initiated on the 8th day of admission, and it was continued every 3 days. About 1 week later, an anti-GBM titer was obtained and exceeded $300 \mathrm{EU}$, and then treatment with $\mathrm{PE}$ and pulse corticosteroid therapy (intravenous administration of methylprednisolone at a dosage of $500 \mathrm{mg} /$ day for 3 days) followed by oral prednisone at $30 \mathrm{mg}$ daily was performed. To achieve renoprotection with blood pressure-lowering and antiproteinuric effects, an angiotensin receptor blocker (candesartan) was used from the early stage of the treatment. Hypertension was well controlled. After three sessions of PE, CRP decreased to the near-normal range and an anti-GBM titer decreased to $60 \mathrm{EU}$. At the 5th week after the initiation of the treatment, HBV DNA became undetectable in the blood and $\mathrm{HBV}$ reactivation never occurred. His Cr level returned to $2.44 \mathrm{mg} / \mathrm{dl}$ and the urinary protein-to-creatinine ratio decreased to $1.1 \mathrm{~g} / \mathrm{g}$ creatinine without hematuria, and he left hospital in the 8th week. After discharge, the patient remained on entecavir with tapering prednisone. An anti-GBM titer finally became negative at the 20th week and remained so since then. His Cr level remained stable between 2.5 and $2.8 \mathrm{mg} /$ $\mathrm{dl}$, and his proteinuria gradually decreased over 6 months to complete remission. No recurrences or relapses have occurred so far. His laboratory data at the latest follow-up showed normal serum transaminases (AST 23 IU/1 and ALT $14 \mathrm{IU} / \mathrm{l})$ and normal serum albumin (3.8 g/dl). His clinical course is shown in Fig. 2.

\section{Discussion}

This case of co-existing anti-GBM glomerulonephritis and secondary $\mathrm{MN}$ is very rare. $\mathrm{MN}$ can be primary or secondary to systemic lupus erythematosus (SLE), chronic infection, malignancy, or drugs. In this case, the patient did not clinically have SLE and the renal biopsy findings were not consistent with those of lupus nephritis. He also denied exposure of offending drugs such as nonsteroidal antiinflammatory drugs (NSAIDs). Considering the patient's pathological findings of stage III-IV MN and the history of $2+$ proteinuria and low serum albumin 3 months before admission, it was reasonable to speculate that the patient was an HBV carrier with detectable HBV DNA level and had, then, undiagnosed HBV-associated MN.

$\mathrm{MN}$ is a well-recognized extrahepatic manifestation of chronic infection with HBV [1]. While primary $\mathrm{MN}$ is evoked by antibodies reacting to planted, endogenous, podocyte-related antigens, recently demonstrated to be the M-type phospholipase $\mathrm{A}_{2}$ receptor $\left(\mathrm{PLA}_{2} \mathrm{R}\right)$ [31, 32], the presence of immune complexes in the kidney suggests an immune complex basis for HBV-associated MN [1]. There are three principal antigens implicated in the pathogenesis of HBV-associated MN. HBsAg, derived from the outer surface envelope of the intact virion, is present in almost all active infections, while hepatitis $\mathrm{B}$ core antigen $(\mathrm{HBcAg}$ ) and $\mathrm{HBeAg}$, associated with the inner viral nucleocapsid, are also thought to be important in the pathogenesis of $\mathrm{MN}$ [1]. HBV-associated $\mathrm{MN}$ is diagnosed clinically by identifying these antigens or their antibodies in a patient with $\mathrm{MN}$ and by excluding other causes of glomerular diseases. Demonstrating these antigens or their antibodies in the 

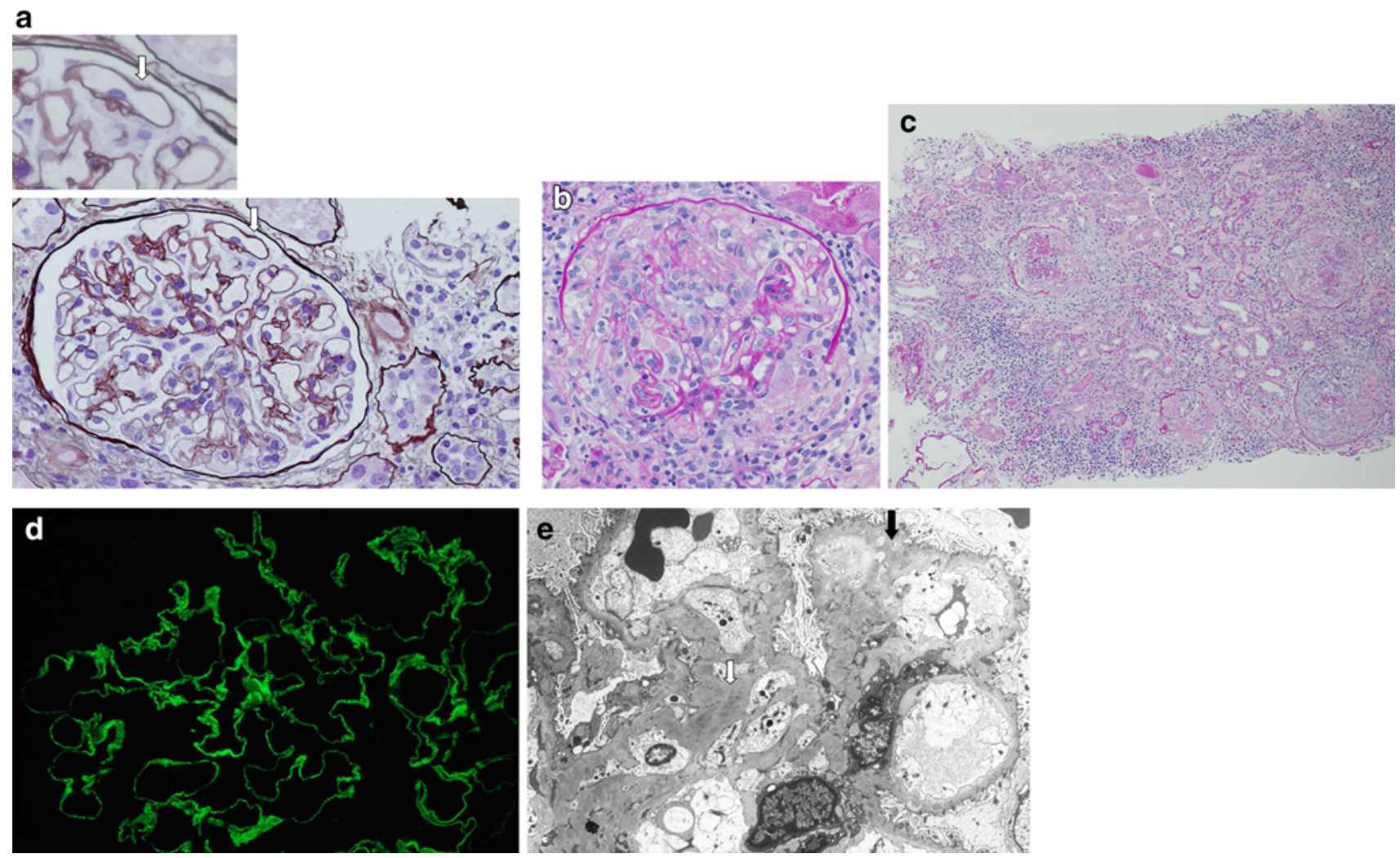

Fig. 1 Renal biopsy specimen. a Periodic acid-silver methenamine (PAM) stain [high-power field (HPF)] showing mild diffuse mesangial proliferation, diffuse thickening of glomerular basement membranes (GBMs), occasional capillary wall subepithelial spikes (arrows), and frequent internal vacuolizations (original magnification, $\times 400 ; \times 1000$ insert; PAM stain). b Periodic acid-Schiff (PAS) stain (HPF) showing cellular crescents and segmental necrosis, with compression or destruction of capillary loops and Bowman's capsule ( $\times$ 400; PAS stain). c PAS stain (low-power field) showing that, around glomeruli with crescent formation, severe tubulointerstitial damage was accompanied by the infiltration of lymphocytes, plasma

glomerular immune complexes can establish an etiologic link. Unfortunately, the glomerular deposition of $\mathrm{HBsAg}$ was not demonstrated in our immunohistochemical specimen. This may be partly because we used paraffinembedded section and had a technical difficulty. Moreover, most patients with $\mathrm{HBV}$-associated $\mathrm{MN}$ have $\mathrm{HBeAg}$, but this patient did not have $\mathrm{HBe} A g$ and showed low $\mathrm{HBV}$ DNA. So, we would have to note that the diagnosis is not definitive. Nevertheless, HBsAg and HBV DNA were diagnostic of active infection, and their continued existence indicated progression to the chronic carrier state, which, consequently, may have induced glomerular diseases in this patient. With respect to histological features, HBVassociated $\mathrm{MN}$ frequently shows mesangial hypercellularity, endocapillary proliferation, and transitional features between MN and MPGN types I and III. In addition, the virus-like spherical microparticles and subendothelial and mesangial deposits seen by electron microscopy are more

cells, neutrophils, and eosinophils, but not by vasculitis $(\times 100$; PAS stain). d Immunofluorescence staining showing diffuse, fine granular staining on capillary loops with an underlying bright linear staining of the GBMs corresponding to anti-GBM antibody $(\times 800)$. e Electron microscopy revealed numerous scattered subepithelial and intramembranous deposits, some of which appear electron-lucent (black arrow), and complete overlying foot process effacement. Morphological clues in this case indicating that the membranous nephropathy $(\mathrm{MN})$ is secondary rather than primary include occasional mesangial deposits and mesangial proliferation (white arrow) $(\times 2000)$

frequent in $\mathrm{HBV}$-associated $\mathrm{MN}$ than in primary $\mathrm{MN}$. Immunopathological studies demonstrate granular GBM deposits of $\operatorname{IgG}$ and, less frequently, C3, IgM, and $\operatorname{IgA}$. This combination of findings is unusual in primary $\mathrm{MN}$, but it is common in HBV-associated MN [33]. The histological features of this case appeared to be compatible with HBVassociated $\mathrm{MN}$ rather than with primary $\mathrm{MN}$.

Clearance of HBV antigens, either spontaneous or following antiviral treatments, results in the improvement of proteinuria. Thus, the prompt diagnosis and specific antiviral treatment are critical in managing patients with $\mathrm{HBV}$ associated MN [1]. It has been argued that corticosteroid and immunosuppressive agents are unfavorable for HBVassociated MN, since they inhibit the immune system, activate latent $\mathrm{HBV}$, and, finally, lead to active replication of HBV, fatal acute hepatitis, and deterioration of renal lesions [34]. In contrast, antiviral drugs have been recommended as the most important therapy for $\mathrm{HBV}$-associated 
Fig. 2 Clinical course. $m P S L$ methylprednisolone, $P S L$ prednisolone, $\mathrm{UP} / \mathrm{Cr}$ spot protein-to-creatinine ratio, $\mathrm{Cr}$ serum creatinine, $\mathrm{Alb}$ serum albumin, $G B M$ anti-GBM antibody
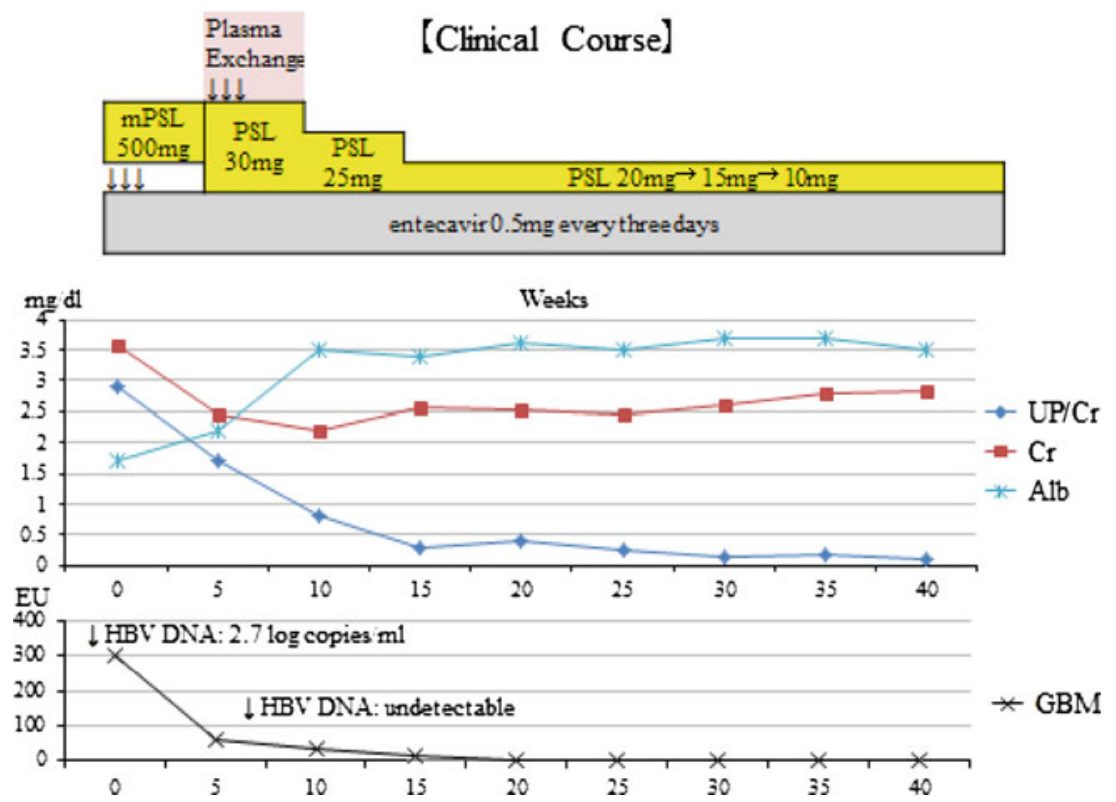

mPSL: methylprednisolone, PSL: prednisolone, UP/Cr: spot protein-to-creatinine ratio, Cr: serum creatinine,

Alb: serum albumin, GBM: anti-GBM antibody
MN. Interferon may lead to the complete remission of proteinuria as well as HBeAg seroconversion [2]. Recently, lamivudine treatment showed a significant decrease in proteinuria and HBV DNA clearance in a year. Cumulative 3-year renal survival was $100 \%$ [3]. However, the incidence of lamivudine-resistant HBV mutant strain is as high as $24 \%$ in 1 year and $53 \%$ in 3 years [35]. In addition, recurrence of proteinuria after cessation of lamivudine is another problem $[3,36]$. On the other hand, entecavir is more preferable in long-term use because of the lower incidence of drug-resistant mutation, which is reported as $1.2 \%$ over 5 years [37]. To the best of our knowledge, there have been only two case reports on the clinical effects of entecavir in HBV-associated glomerulonephritis [38, 39]. We believe the present report to be the first showing the efficacy of entecavir in combination with PE and corticosteroid. Entecavir is a nucleoside analogue that inhibits HBV DNA polymerase at both the priming and elongating steps of DNA synthesis. It has been shown to be more effective than lamivudine in suppressing viral replication [40]. Entecavir appears to be safe in patients with chronic kidney diseases, but the dose needs to be adjusted in patients with renal dysfunction, as in our patient. Moreover, in recent years, cases of HBV reactivation and fatal acute hepatitis either during or following immunosuppressive therapy or chemotherapy in HBsAg-negative patients with past HBV infection, as well as HBsAg- and $\mathrm{HBeAb}$-positive inactive carriers, have been increasingly reported. These are serious issues which should be made aware of [41-43]. Preemptive use of entecavir has also enabled the successful management of HBV reactivation [44]. Treatment duration may be another important factor affecting the clinical outcome. HBV-associated MN may require long-term antiviral therapy. Although cost-related issues as well as resistance to entecavir need to be evaluated further, we will continue entecavir to prevent the potential recurrence of proteinuria and anti-GBM glomerulonephritis in this patient.

The rapid decline of renal function in patients with MN may be due to several causes, including malignant hypertension, renal vein thrombosis, tubulointerstitial nephritis, and crescentic glomerulonephritis [45]. Crescents are rare in primary $\mathrm{MN}$ and, thus, suggest another underlying disease process. There is evidence for at least two pathogenetic mechanisms in the crescentic formation seen in patients with MN. The first mechanism occurs in the presence of anti-GBM antibodies. The second occurs more often in association with ANCA [33]. Moreover, many patients with crescentic $\mathrm{MN}$ have neither anti-GBM antibodies nor ANCA, and the pathogenesis of crescentic glomerulonephritis in these patients is of wide variety. The first case of combined membranous and crescentic glomerulonephritis associated with anti-GBM antibodies was reported by Klassen et al. in 1974 [4]. Since then, there have been 27 published case reports or articles in the literature that have been associated with high mortality and morbidity, and a very high rate of progression to end-stage renal disease (ESRD) (Table 1). To the best of our knowledge, our patient was the oldest reported case to date. Anti-GBM glomerulonephritis superimposed on secondary 
Table 1 Reports observing the chronologic relationship between membranous nephropathy (MN) and anti-glomerular basement membrane (GBM) disease

\begin{tabular}{|c|c|c|c|c|}
\hline Reference & $\begin{array}{l}\text { Age/ } \\
\text { gender }\end{array}$ & Clinical presentation & Therapy & Outcome \\
\hline \multicolumn{5}{|l|}{ Group 1} \\
\hline Klassen et al. [4] & 49/M & Edema, chest pain, anuria & Steroids & Died of seizure \\
\hline $\begin{array}{l}\text { Moorthy et al., case } 1 \\
\text { [5] }\end{array}$ & $53 / \mathrm{M}$ & Edema & Steroids, azathioprine & Hemodialysis \\
\hline $\begin{array}{l}\text { Richman et al., case } 1 \\
\text { [6] }\end{array}$ & $65 / \mathrm{M}$ & Edema, renal failure & Steroids, CP, PP & $\begin{array}{l}\text { Died of myocardial } \\
\text { infarction }\end{array}$ \\
\hline Kurki et al. [7] & $54 / \mathrm{M}$ & Cough, arthralgia, pleurisy, nephritic & Steroids, PP & ESRD, transplant \\
\hline Thitiarchakul et al. [8] & $57 / ?$ & $\begin{array}{l}\text { Edema, vomiting, shortness of breath, } \\
\text { hemoptysis }\end{array}$ & Steroids, CP, PP & Hemodialysis \\
\hline Nayak and Satish [9] & $54 / \mathrm{F}$ & Edema, oliguria, vomiting & Steroids, CP, PP & Hemodialysis \\
\hline \multicolumn{5}{|l|}{ Group 2} \\
\hline Agodoa et al. [10] & $22 / \mathrm{F}$ & Cough, weakness, syncope, hematuria & None & Recovery \\
\hline $\begin{array}{l}\text { Savige et al., case } 5 \\
\text { [11] }\end{array}$ & 20/M & Hematuria & "Cytotoxic drugs," PP & Recovery \\
\hline $\begin{array}{l}\text { Savige et al., case } 6 \\
\text { [11] }\end{array}$ & $18 / \mathrm{F}$ & Hematuria & PP, steroids, CP & Chronic kidney disease \\
\hline Elder et al. [12] & 20/M & Hemoptysis, dyspnea, fever, hematuria & Steroids, CP & Recovery, proteinuria \\
\hline Keilstein et al. [13] & $17 / \mathrm{M}$ & Hemoptysis, hematuria & Antibiotics & Recovery \\
\hline Hecht et al. [14] & $9 / \mathrm{F}$ & Abdominal pain, emesis, malaise, hematuria & $\begin{array}{l}\text { Steroids, CP, PP, } \\
\text { cyclosporine }\end{array}$ & Recovery \\
\hline \multicolumn{5}{|l|}{ Group 3} \\
\hline $\begin{array}{l}\text { Moorthy et al., case } 2 \\
\text { [5] }\end{array}$ & 44/M & Ankle edema & Steroids & Dialysis \\
\hline Pasternack et al. [15] & $19 / \mathrm{F}$ & Hemoptysis, hematuria & Steroids, azathioprine & Nephrectomy, dialysis \\
\hline Sharon et al. [16] & $25 / \mathrm{M}$ & Hemoptysis, hematuria, edema & Steroids, CP, PP & $\begin{array}{l}\text { Died (pulmonary } \\
\text { hemorrhage) }\end{array}$ \\
\hline $\begin{array}{l}\text { Richman et al., case } 2 \\
\text { [6] }\end{array}$ & $65 / \mathrm{M}$ & Hemoptysis & Steroids, azathioprine & $\begin{array}{l}\text { Died (pulmonary } \\
\text { hemorrhage) }\end{array}$ \\
\hline Jennette et al. [17] & $17 / \mathrm{M}$ & Sore throat, fever, minimal hemoptysis & Steroids, CP & Recovery \\
\hline $\begin{array}{l}\text { Tomaszewski et al. } \\
{[18]}\end{array}$ & $22 / \mathrm{F}$ & Hemoptysis, hematuria & NA & NA \\
\hline Pettersson et al. [19] & $20 / \mathrm{M}$ & Sore throat, fever, lumbar pain, hematuria & Steroids, PP & Recovery \\
\hline $\begin{array}{l}\text { Savige et al., case } 1 \\
\text { [11] }\end{array}$ & $16 / \mathrm{F}$ & Hemoptysis, hematuria, edema & Steroids, CP, PP & Recovery \\
\hline $\begin{array}{l}\text { Savige et al., case } 2 \\
\text { [11] }\end{array}$ & $47 / \mathrm{M}$ & History of hematuria, anuria & NA & Dialysis, transplant \\
\hline $\begin{array}{l}\text { Savige et al., case } 3 \\
\text { [11] }\end{array}$ & $21 / \mathrm{M}$ & Hematuria, hemoptysis & Steroids, CP, PP & Recovery \\
\hline $\begin{array}{l}\text { Savige et al., case } 4 \\
\text { [11] }\end{array}$ & $20 / \mathrm{F}$ & Hematuria, anemia & Steroids, CP, PP & Recovery \\
\hline Hayano et al. [20] & $60 / \mathrm{M}$ & Prolonged anorexia, general malaise & Steroids, PP & Dialysis \\
\hline Takeuchi et al. [21] & $70 / \mathrm{M}$ & Acute renal failure & Steroids, CP, PP & Died (unclear) \\
\hline Meisels et al. [22] & $50 / \mathrm{M}$ & Edema for 4 months, then hematuria & Steroids, CP, PP & Recovery \\
\hline Sano et al. [23] & $54 / \mathrm{F}$ & Hematuria, proteinuria, acute renal failure & Steroids, PP & Dialysis \\
\hline Nasr et al. [24] & $53 / \mathrm{M}$ & $\begin{array}{l}\text { Cough, sore throat, fatigue, dyspnea, } \\
\text { hematuria }\end{array}$ & Steroids, CP, PP & Dialysis \\
\hline Singh et al. [25] & $48 / \mathrm{F}$ & Anuria & Steroids, CP, PP & Dialysis \\
\hline Hoshino et al. [26] & $71 / \mathrm{F}$ & $\begin{array}{l}\text { Fatigue, nausea, pitting edema, pulmonary } \\
\text { edema }\end{array}$ & Steroids & Renal insufficiency \\
\hline Troxell et al. [27] & $49 / \mathrm{M}$ & Fatigue, hematuria, flank pain & Steroids, CP, PP & Dialysis \\
\hline
\end{tabular}


Table 1 continued

\begin{tabular}{lllll}
\hline Reference & $\begin{array}{l}\text { Age/ } \\
\text { gender }\end{array}$ & Clinical presentation & Therapy & Outcome \\
\hline Cui et al. [28] & 20/M & Hematuria, generalized edema & NA & Dialysis \\
Cui et al. [28] & 40/M & Hematuria & Steroids, CP, PP & Dialysis \\
Cui et al. [28] & 40/F & Upper respiratory tract infection, hematuria & Steroids, CP, PP & Renal insufficiency \\
Patel et al. [29] & $59 / \mathrm{M}$ & Nausea, vomiting, renal insufficiency & Steroids, CP, PP & Dialysis \\
Basford et al. [30] & $59 / \mathrm{M}$ & Fatigue, hematuria, acute renal failure & Steroids, CP, PP & Recovery \\
Present case & $76 / \mathrm{M}$ & Fever, persistent cough, general fatigue, leg & Steroids, PP, entecavir & Renal insufficiency \\
& & edema & & \\
\hline
\end{tabular}

Group 1 MN followed by anti-GBM disease, Group 2 primary anti-GBM disease followed by granular subepithelial deposits, Group 3 simultaneous detection of both lesions, $M$ male, $F$ female, $C P$ cyclophosphamide, $P P$ plasmapheresis, $N A$ not available. Adapted from Basford et al. [30]

MN such as HBV-associated MN is exceptionally rare, since there has been only one case reported in the literature [28]. There have been several reviews of the literature and it has been observed that the chronologic relationship between MN and anti-GBM disease fell into three patterns: (1) MN followed by anti-GBM disease, (2) primary antiGBM disease followed by granular subepithelial deposits, and (3) simultaneous detection of both lesions [19, 24, 26, $29,30]$.

Anti-GBM disease is a rare form of autoimmune disorder with significant morbidity and mortality, and is characterized by crescentic glomerulonephritis, often accompanied by pulmonary hemorrhage and the presence of circulating and deposited anti-GBM antibodies [46]. The disease is caused by antibodies against the noncollagenous $\mathrm{NC} 1$ domain of the $\alpha 3$ (and, to a lesser extent, the $\alpha 5$ ) chains of type IV collagen, which contains two conformational epitopes, designated $\mathrm{E}_{\mathrm{A}}$ and $\mathrm{E}_{\mathrm{B}}$ [47, 48]. The etiology of anti-GBM disease is unclear, but a recent study has suggested that the development of the disease may be considered as an autoimmune "conformeropathy" that involves perturbation of the quaternary structure of the $\alpha 345 \mathrm{NC} 1$ hexamer, inducing a pathogenic conformational change in the $\alpha 3 \mathrm{NC} 1$ and $\alpha 5 \mathrm{NC} 1$ subunits [48]. Although a pathogenetic relationship between anti-GBM disease and MN remained speculative, the co-existence of these lesions may be immune-mediated. One hypothesis from the viewpoint of the chronologic relationship suggests that the subepithelial and intramembranous immune complex deposition found in primary or secondary MN may cause the release of normal or altered GBM antigens into the circulation or unmask cryptic type IV collagen epitopes, leading to both nephritogenic anti-GBM antibodies production and binding, which, in turn, elicits an autoimmune response. In fact, Borza et al. have demonstrated that cryptic type IV collagen epitopes are more easily exposed in collagen hexamers lacking structural reinforcement, as expected in newly synthesized or remodeled GBM in the setting of MN [47]. This process might be the mechanism in most of the patients with MN followed by anti-GBM disease and simultaneous detection of both lesions. Alternatively, in a few patients with primary anti-GBM disease followed by granular subepithelial deposits, immunologic mechanisms involved in the pathogenesis of anti-GBM disease may directly or indirectly lead to the genesis of membranous-type deposits. It has been proposed in analogy to the model of Heymann nephritis that membranoustype deposits may subsequently arise from in situ immune complex formation in the setting of anti-GBM disease in association with increased antigen synthesis by injured podocytes, facilitated by the capping and shedding of antigen-antibody complexes into the subepithelial space [24, 27, 29, 30, 49]. Also, anti-GBM antibodies might alter the permeability of GBM, allowing circulating immune complexes to access otherwise inaccessible parts of the GBM [12-14, 28].

The outcome in our patient was excellent. The reasons for such success may include the low percentage of glomeruli with crescent formation and the prominence of tubulointerstitial damages, which may have responded well to corticosteroid therapy, permitting functional recovery. Fortunately, the patient did not suffer from any opportunistic infection or HBV reactivation during the course of treatment. To avoid infectious complication, corticosteroid pulse therapy without potent immunosuppressants, such as cyclophosphamide, represents a relatively safe immunosuppressive regimen and may be a good initial choice, especially in immunocompromised patients without pulmonary hemorrhage who have interstitial renal damage, as in our patient. Intriguingly, our patient has remained in remission with minimal proteinuria, stable serum creatinine, and with minimal side effects from therapy 12 months after presentation. The remission of proteinuria and stable creatinine, in parallel with the decreased level of HBV DNA and anti-GBM titer, by the treatment of entecavir with tapering prednisone further suggests the possibility that 
HBV-associated $\mathrm{MN}$ and anti-GBM glomerulonephritis could be pathogenically linked in this patient.

In conclusion, we report here the rare case of anti-GBM glomerulonephritis superimposed on $\mathrm{HBV}$-associated MN who was successfully treated with a combination of PE, corticosteroid, and entecavir. In addition, the efficacy of entecavir and the importance of the prevention of $\mathrm{HBV}$ reactivation in immunosuppressive therapy are also underscored by this case. Co-existing anti-GBM glomerulonephritis and $\mathrm{MN}$ is rare, and relatively little is known about the etiology, pathogenesis, treatment, and prognosis. This case report should provide useful insight into these aspects of this combined disease.

Conflict of interest None.

\section{References}

1. Bhimma R, Coovadia HM. Hepatitis B virus-associated nephropathy. Am J Nephrol. 2004;24:198-211.

2. Lin CY. Treatment of hepatitis B virus-associated membranous nephropathy with recombinant alpha-interferon. Kidney Int. 1995;47:225-30.

3. Tang S, Lai FM, Lui YH, Tang CS, Kung NN, Ho YW, Chan KW, Leung JC, Lai KN. Lamivudine in hepatitis B-associated membranous nephropathy. Kidney Int. 2005;68:1750-8.

4. Klassen J, Elwood C, Grossberg AL, Milgrom F, Montes M, Sepulveda M, Andres GA. Evolution of membranous nephropathy into anti-glomerular-basement-membrane glomerulonephritis. N Engl J Med. 1974;290:1340-4.

5. Moorthy AV, Zimmerman SW, Burkholder PM, Harrington AR. Association of crescentic glomerulonephritis with membranous glomerulonephropathy: a report of three cases. Clin Nephrol. 1976;6:319-25.

6. Richman AV, Rifkin SI, McAllister CJ. Rapidly progressive glomerulonephritis. Combined antiglomerular basement membrane antibody and immune complex pathogenesis. Hum Pathol. 1981;12:597-604.

7. Kurki P, Helve T, von Bonsdorff M, Törnroth T, Pettersson E, Riska H, Miettinen A. Transformation of membranous glomerulonephritis into crescentic glomerulonephritis with glomerular basement membrane antibodies. Serial determinations of antiGBM before the transformation. Nephron. 1984;38:134-7.

8. Thitiarchakul S, Lal SM, Luger A, Ross G. Goodpasture's syndrome superimposed on membranous nephropathy. A case report. Int J Artif Organs. 1995;18:763-5.

9. Nayak SG, Satish R. Crescentic transformation in primary membranous glomerulopathy: association with anti-GBM antibody. Saudi J Kidney Dis Transpl. 2007;18:599-602.

10. Agodoa LC, Striker GE, George CR, Glassock R, Quadracci LJ. The appearance of nonlinear deposits of immunoglobulins in Goodpasture's syndrome. Am J Med. 1976;61:407-13.

11. Savige JA, Dowling J, Kincaid-Smith P. Superimposed glomerular immune complexes in anti-glomerular basement membrane disease. Am J Kidney Dis. 1989;14:145-53.

12. Elder G, Perl S, Yong JL, Fletcher J, Mackie J. Progression from Goodpasture's disease to membranous glomerulonephritis. Pathology. 1995;27:233-6.

13. Kielstein JT, Helmchen U, Netzer KO, Weber M, Haller H, Floege J. Conversion of Goodpasture's syndrome into membranous glomerulonephritis. Nephrol Dial Transplant. 2001;16:2082-5.

14. Hecht N, Omoloja A, Witte D, Canessa L. Evolution of antiglomerular basement membrane glomerulonephritis into membranous glomerulonephritis. Pediatr Nephrol. 2008;23:477-80.

15. Pasternack A, Törnroth T, Linder E. Evidence of both anti-GBM and immune complex mediated pathogenesis in the initial phase of Goodpasture's syndrome. Clin Nephrol. 1978;9:77-85.

16. Sharon Z, Rohde RD, Lewis EJ. Report of a case of Goodpasture's syndrome with unusual immunohistology and antibody reactivity. Clin Immunol Immunopathol. 1981;18:402-14.

17. Jennette JC, Lamanna RW, Burnette JP, Wilkman AS, Iskander SS. Concurrent antiglomerular basement membrane antibody and immune complex mediated glomerulonephritis. Am J Clin Pathol. 1982;78:381-6.

18. Tomaszewski MM, Hassell LH, Moore J Jr, Antonovych TT. Goodpasture's syndrome-local and diffuse deposition of antibody in glomerular basement membrane. Case report. Clin Nephrol. 1983;20:44-8.

19. Pettersson E, Törnroth T, Miettinen A. Simultaneous anti-glomerular basement membrane and membranous glomerulonephritis: case report and literature review. Clin Immunol Immunopathol. 1984;31:171-80.

20. Hayano K, Miura H, Fukui H, Otsuka Y, Hattori S. A case of anti-GBM nephritis (crescentic glomerulonephritis) associated with membranous nephropathy. Nihon Jinzo Gakkai Shi. 1992;34:821-6.

21. Takeuchi K, Takeda T, Sakai I, Taneichi K, Shibaki H. An autopsy case of Goodpasture syndrome preceded with membranous glomerulonephritis. Ryumachi. 1997;37:781-7.

22. Meisels IS, Stillman IE, Kuhlik AB. Anti-glomerular basement membrane disease and dual positivity for antineutrophil cytoplasmic antibody in a patient with membranous nephropathy. Am J Kidney Dis. 1998;32:646-8.

23. Sano T, Kamata K, Shigematsu H, Kobayashi Y. A case of antiglomerular basement membrane glomerulonephritis superimposed on membranous nephropathy. Nephrol Dial Transplant. 2000;15:1238-41.

24. Nasr SH, Ilamathi ME, Markowitz GS, D’Agati VD. A dual pattern of immunofluorescence positivity. Am J Kidney Dis. 2003;42:419-26.

25. Singh A, Arif F, Mangat S, Ames R, Douglas C. Quiz page. Acute cellular crescentic glomerulonephritis in association with anti-glomerular basement membrane disease and superimposed membranous nephropathy. Am J Kidney Dis. 2004;43:A48, e1.

26. Hoshino J, Hara S, Ubara Y, Takaya H, Suwabe T, Sawa N, Tagami T, Katori H, Takemoto F, Hara S, Takaichi K. Distribution of IgG subclasses in a biopsy specimen showing membranous nephropathy with anti-glomerular basement membrane glomerulonephritis: an uncharacteristically good outcome with corticosteroid therapy. Am J Kidney Dis. 2005;45:e67-72.

27. Troxell ML, Saxena AB, Kambham N. Concurrent anti-glomerular basement membrane disease and membranous glomerulonephritis: a case report and literature review. Clin Nephrol. 2006;66:120-7.

28. Cui Z, Zhao MH, Wang SX, Liu G, Zou WZ, Wang HY. Concurrent antiglomerular basement membrane disease and immune complex glomerulonephritis. Ren Fail. 2006;28:7-14.

29. Patel D, Nivera N, Tunkel AR. Anti-glomerular basement membrane disease superimposed on membranous nephropathy: a case report and review of the literature. J Med Case Rep. 2010;4:237.

30. Basford AW, Lewis J, Dwyer JP, Fogo AB. Membranous nephropathy with crescents. J Am Soc Nephrol. 2011;22:1804-8.

31. Beck LH Jr, Bonegio RG, Lambeau G, Beck DM, Powell DW, Cummins TD, Klein JB, Salant DJ. M-type phospholipase $\mathrm{A}_{2}$ 
receptor as target antigen in idiopathic membranous nephropathy. N Engl J Med. 2009;361:11-21.

32. Ronco P, Debiec H. Antigen identification in membranous nephropathy moves toward targeted monitoring and new therapy. J Am Soc Nephrol. 2010;21:564-9.

33. Schwartz MM. Membranous glomerulonephritis. In: Jennette JC, Olson JL, Schwartz MM, Silva FG, editors. Heptinstall's pathology of the kidney. 6th ed. Philadelphia: Lippincott Williams \& Wilkins; 2007. p. 205-51.

34. Elewa U, Sandri AM, Kim WR, Fervenza FC. Treatment of hepatitis B virus-associated nephropathy. Nephron Clin Pract. 2011;119:c41-9.

35. Lai CL, Dienstag J, Schiff E, Leung NW, Atkins M, Hunt C, Brown N, Woessner M, Boehme R, Condreay L. Prevalence and clinical correlates of YMDD variants during lamivudine therapy for patients with chronic hepatitis B. Clin Infect Dis. 2003;36:687-96.

36. Mesquita M, Lasser L, Langlet P. Long-term (7-year-) treatment with lamivudine monotherapy in HBV-associated glomerulonephritis. Clin Nephrol. 2008;70:69-71.

37. Tenney DJ, Rose RE, Baldick CJ, Pokornowski KA, Eggers BJ, Fang J, Wichroski MJ, Xu D, Yang J, Wilber RB, Colonno RJ. Long-term monitoring shows hepatitis B virus resistance to entecavir in nucleoside-naïve patients is rare through 5 years of therapy. Hepatology. 2009;49:1503-14.

38. Ikee R, Ishioka K, Oka M, Maesato K, Moriya H, Hidaka S, Ohtake T, Kobayashi S. Hepatitis B virus-related membranous nephropathy treated with entecavir. Nephrology (Carlton). 2010;15:266.

39. Sakai K, Morito N, Usui J, Hagiwara M, Hiwatashi A, Fukuda K, Nanmoku T, Toda T, Matsui N, Nagata M, Yamagata K. Focal segmental glomerulosclerosis as a complication of hepatitis $\mathrm{B}$ virus infection. Nephrol Dial Transplant. 2011;26:371-3.

40. Lai CL, Rosmawati M, Lao J, Van Vlierberghe H, Anderson FH, Thomas N, Dehertogh D. Entecavir is superior to lamivudine in reducing hepatitis $\mathrm{B}$ virus DNA in patients with chronic hepatitis B infection. Gastroenterology. 2002;123:1831-8.
41. Hui CK, Cheung WW, Zhang HY, Au WY, Yueng YH, Leung AY, Leung N, Luk JM, Lie AK, Kwong YL, Liang R, Lau GK. Kinetics and risk of de novo hepatitis B infection in HBsAgnegative patients undergoing cytotoxic chemotherapy. Gastroenterology. 2006;131:59-68.

42. Yeo W, Chan TC, Leung NW, Lam WY, Mo FK, Chu MT, Chan HL, Hui EP, Lei KI, Mok TS, Chan PK. Hepatitis B virus reactivation in lymphoma patients with prior resolved hepatitis B undergoing anticancer therapy with or without rituximab. J Clin Oncol. 2009;27:605-11.

43. Ohishi W, Chayama K. Prevention of hepatitis B virus reactivation in immunosuppressive therapy or chemotherapy. Clin Exp Nephrol. 2011;15:634-40.

44. Matsue K, Kimura S, Takanashi Y, Iwama K, Fujiwara H, Yamakura M, Takeuchi M. Reactivation of hepatitis B virus after rituximab-containing treatment in patients with $\mathrm{CD} 20$-positive B-cell lymphoma. Cancer. 2010;116:4769-76.

45. Nguyen BP, Reisin E, Rodriguez FH Jr. Idiopathic membranous glomerulopathy complicated by crescentic glomerulonephritis and renal vein thrombosis. Am J Kidney Dis. 1988;12:326-8.

46. Salama AD, Levy JB, Lightstone L, Pusey CD. Goodpasture's disease. Lancet. 2001;358:917-20.

47. Borza DB, Bondar O, Colon S, Todd P, Sado Y, Neilson EG, Hudson BG. Goodpasture autoantibodies unmask cryptic epitopes by selectively dissociating autoantigen complexes lacking structural reinforcement: novel mechanisms for immune privilege and autoimmune pathogenesis. J Biol Chem. 2005;280:27147-54.

48. Pedchenko V, Bondar O, Fogo AB, Vanacore R, Voziyan P, Kitching AR, Wieslander J, Kashtan C, Borza DB, Neilson EG, Wilson CB, Hudson BG. Molecular architecture of the Goodpasture autoantigen in anti-GBM nephritis. $\mathrm{N}$ Engl $\mathrm{J}$ Med. 2010;363:343-54.

49. Kerjaschki D, Neale TJ. Molecular mechanisms of glomerular injury in rat experimental membranous nephropathy (Heymann nephritis). J Am Soc Nephrol. 1996;7:2518-26. 